\title{
Seasonal variation in oceanographic habitat and behaviour of white-chinned petrels Procellaria aequinoctialis from Kerguelen Island
}

\author{
Clara Péron ${ }^{1, *}$, Karine Delord ${ }^{1}$, Richard A. Phillips ${ }^{2}$, Yohan Charbonnier ${ }^{1}$, \\ Cédric Marteau $^{3}$, Maité Louzao ${ }^{1,4}$, Henri Weimerskirch ${ }^{1}$ \\ ${ }^{1}$ Centre d'Etudes Biologiques de Chizé, CNRS UPR 1934, 79369 Villiers en Bois, France \\ ${ }^{2}$ British Antarctic Survey, Natural Environment Research Council, High Cross, Madingley Road, Cambridge CB3 0ET, UK \\ ${ }^{3}$ Terres Australes et Antarctiques Françaises, rue Gabriel Dejean, 97458 St Pierre - BP 400- La Réunion, France \\ ${ }^{4}$ Helmholtz Centre for Environmental Research - UFZ, Permoserstrasse 15, 04318 Leipzig, Germany
}

\begin{abstract}
Marine environments experience seasonal variation in physical and biological parameters, with consequent changes in predator distributions. During the breeding period, proximity to suitable feeding sites is essential for central place foragers, whereas during the non-breeding period their distribution is relatively unconstrained. We combined light-based geolocation and satellite tracking to investigate seasonal variation in foraging grounds and behaviour of white-chinned petrels from Kerguelen Island. Birds were associated with highly productive areas throughout the year. During breeding (summer), they performed long commuting trips from the colony to distant, productive Antarctic waters. Thereafter, birds migrated $5200 \mathrm{~km}$ westwards to the Benguela upwelling system off Namibia and South Africa to spend the winter. This seasonal shift of foraging grounds coincides with a change in activity patterns; much less time was spent in flight in winter than in summer. Individual variability in the locations of foraging zones and seasonal/daily activity patterns was low. Trip durations were shorter during chick-rearing than incubation, although birds often travelled as far or farther, tracking the gradual break up of pack ice. Habitat use models revealed an association with distance to sea-ice edge and chlorophyll a gradient during incubation, whereas sea surface temperature and chlorophyll a gradient best explained habitat use during chick rearing. White-chinned petrels are likely to overlap with other marine predators and fisheries throughout the year. Fishery bycatch constitutes the most significant direct threat to petrels at sea. Moreover, future climate-induced reductions in productivity could affect birds year-round.
\end{abstract}

KEY WORDS: Foraging behaviour · Activity · Breeding $\cdot$ Non-breeding ground $\cdot$ Upwelling $\cdot$ Sea ice . Bycatch $\cdot$ Geolocation $\cdot$ Satellite tracking

\section{INTRODUCTION}

Within dynamic environments, animals track highly productive habitats, changing their foraging grounds and strategies depending on food availability in order to fulfil their energetic requirements and, consequently, maximize fitness. Marine environments undergo seasonal patterns in primary productivity, especially at higher latitudes; hence, resources available to marine species are heterogeneous in space and time, leading to changes in predator distribution (Polovina et al. 2001). Foraging grounds are also determined by species dispersal capacity and energy requirements, which may vary during the annual cycle (Green et al. 2009). Seabirds are central place foragers during the breeding season, having to commute between their colonies and feeding zones at sea to provision their offspring. This strategy imposes energetic constraints 
which limit foraging range and thus accessibility of certain marine habitats. Breeding occurs generally during summer, when productivity is highest. During the non-breeding season, birds can disperse over wide areas or migrate to completely different habitats as they do not have to return to the colony (Shaffer et al. 2006, Bost et al. 2009, Egevang et al. 2010).

An increasing number of studies apply habitat use models to provide insights into the oceanographic cues that drive marine top predator distribution (Tremblay et al. 2009). To date, few studies have quantified how key oceanic habitats exploited by marine top predators change year-round across the dynamic marine environment (Phillips et al. 2006, González-Solís et al. 2007b). Yet, providing information on spatial distribution and habitat use of a species throughout the year is essential to identify and predict regional effects of climate change over the species' entire range and to assess direct population-level threats such as fishery bycatch. These potential threats could then be included in demographic models to assess their relative influence on population dynamics (e.g. Rolland et al. 2008). Tracking data now enable the exploration of relationships between animal movements/behaviour and oceanographic variables at different spatial scales (Pinaud \& Weimerskirch 2007). These can be combined in models to predict potential habitats at sea for birds from untracked sites and populations (Louzao et al. 2009). The purposes of habitat modelling are to (1) explain species-habitat relationships through robust mathematical description, and (2) provide spatially explicit habitat predictions based on key variables. They are becoming essential tools to drive marine conservation initiatives and guide the establishment of marine protected areas (Cañadas et al. 2005, Louzao et al. 2006).

Until recently, most studies of seabird distribution focused on the breeding season (Weimerskirch et al. 1994, Hyrenbach et al. 2002, Pinaud \& Weimerskirch 2007), when birds are central place foragers and more amenable to short-term deployment and recovery of tracking devices (Phillips et al. 2004). The recent advent of miniaturized light-based geolocators (Global Location Sensors, weight $<3 \mathrm{~g}$ ) has enabled tracking of individuals of known origin and status for long time periods. Despite reduced accuracy (Phillips et al. 2004), this method allows the investigation of seabird migration patterns and non-breeding distributions, traditionally based on rare and opportunistic band recoveries or ship-based observations (Tuck et al. 1999). Moreover, continuous recordings of wet/dry activity (immersion) provides additional information on at-sea activity patterns by day and night along the whole track (Phalan et al. 2007, Phillips et al. 2007).
Here, we focused on a species of high conservation concern, the white-chinned petrel Procellaria aequinoctialis. Although one of the most abundant seabirds in the Southern Ocean, occurring throughout mid and high latitudes, this petrel is classified as Vulnerable in the IUCN red list (BirdLife International 2010). Their ship-following behaviour (Ryan \& Moloney 1988) and ability to feed actively during both night and day make them highly susceptible to fisheries bycatch (Weimerskirch et al. 2000a). As a consequence, tens of thousands of individuals are killed each year when attempting to secure bait from longline hooks, or in interactions with trawl-net warps (Barnes et al. 1997, Watkins et al. 2008). This species experiences amongst the highest bycatch rates of any seabird in the Southern Ocean (Phillips et al. 2006). Long-term population declines inferred from analysis of at-sea observations in the southern Indian Ocean (Woehler 1996, Péron et al. 2010) are corroborated by land-based censuses at Marion, South Georgia and Crozet Islands (Berrow et al. 2000, Nel et al. 2002, Barbraud et al. 2008, Martin et al. 2009). In addition to being susceptible to fisheries bycatch, white-chinned petrels are affected by climatic variability in the marine environment (Barbraud et al. 2008), and it is thus essential to better understand the habitats used by this species throughout its annual cycle.

By combining tracking data from geolocators and satellite transmitters, we assessed how petrels cope with seasonal changes in food availability throughout the year, at large and medium spatial scales, respectively. We investigated seasonal and daily variation in at-sea activity patterns to provide new insights on foraging strategies. Using habitat modelling, we identified the key oceanographic determinants of whitechinned petrel summer foraging distribution and generated spatially explicit predictions of petrel habitat utilisation.

\section{MATERIALS AND METHODS}

Study site and species ecology. The study was carried out at the 'Cañon des Sourcils Noirs', a colony of white-chinned petrels, located at the south-east of Kerguelen Island $\left(70^{\circ} 15^{\prime} 43 \mathrm{E}, 49^{\circ} 36^{\prime} 21 \mathrm{~S}\right)$. This subantarctic island holds the largest population of whitechinned petrels in the southern Indian Ocean, estimated recently at 186000 to 297000 breeding pairs (Barbraud et al. 2009). White-chinned petrels (mass 1.0 to $1.2 \mathrm{~kg}$ ) are burrow-nesting seabirds that breed annually. Their breeding season lasts $\sim 5$ mo. Adults arrive at the colony in October to copulate, and after a pre-laying exodus of 2 to $3 \mathrm{wk}$ at sea, females lay a single egg in late November (Mougin 1968, Jouventin 
et al. 1985, Phillips et al. 2006). Chicks hatch in January and fledge in April (Jouventin et al. 1985). At other breeding localities, male and female white-chinned petrels alternate incubation duties, performing long foraging trips lasting approximately $2 \mathrm{wk}_{\text {; }}$ in contrast, during chick-rearing at South Georgia, trips are much shorter, and at Crozet, birds alternate between long and short trips (dual strategy) (Catard et al. 2000, Phillips et al. 2006). Chicks are left alone in their burrow after they have acquired thermal independence ( 2 to $6 \mathrm{~d})$.

Tracking with geolocators. For the large scale study of movements we used Global Location Sensing (GLS) loggers that allow estimates of latitudes and longitude from light measurements (Wilson et al. 1992) and provide low accuracy locations (Phillips et al. 2004). We deployed 30 GLS loggers (developed by the British Antarctic Survey, Cambridge) on breeding adults in late November 2005 (10 ind.) and December 2007 (20 ind.). Loggers were mounted on plastic leg bands and weighed $5 \mathrm{~g}$ (Mk4), $2.5 \mathrm{~g}$ (Mk9) or $1.5 \mathrm{~g}$ (Mk13), which are well below the $3 \%$ limit recommended for flying birds (Phillips et al. 2003). The recovery rate was $80 \%$; 2 individuals were left with loggers during 3 consecutive years and 1 individual was equipped for $1 \mathrm{yr}$ in 2005 and 2007 (see Table S1 in the supplement at www.int-res.com/articles/suppl/m416p267_supp.pdf for details on GLS equipment). The loggers operate with an internal clock and measure the light level every minute, recording the maximum reading within each 10 min block (Afanasyev 2004). Two positions per day can be inferred from the light signal with an average accuracy of $186 \mathrm{~km}( \pm 114 \mathrm{~km})$, estimated for freeranging albatrosses (Phillips et al. 2004). Positions were calculated using MULTITRACE 3/16 light (www. jensen-software.com/) based on timing of dawn and dusk, noting any transitions that may have been unreliable because of interruptions to light curves. Filtering procedure and statistical analyses were performed using the $\mathrm{R}$ software ( $\mathrm{R}$ Development Core Team 2009). We removed unrealistic positions that were obtained: (1) from light curves showing major interferences at dawn or dusk, (2) those yielding unrealistic flight speeds (McConnell et al. 1992; speed threshold = $20 \mathrm{~m} \mathrm{~s}^{-1}$ ) and (3) those around equinox periods (20/21 March and 22/23 September), when latitude cannot be estimated (Wilson et al. 1992). The high proportion of erroneous locations $(50,68$ and $81 \%$ during the non-breeding, breeding and pre-laying exodus period, respectively) are mainly attributable to equinox periods and interferences to the light curve because of intermittent shading of the sensor when birds tuck their leg in their plumage. Interference in the light signal was evident throughout the year but greatest during breeding and the pre-laying exodus, when birds spent more time in flight. The speed threshold was set to $20 \mathrm{~m} \mathrm{~s}^{-1}$, based on the maximum mean velocity of white-chinned petrels estimated from fine resolution GPS (Global Positioning System) tracks (H. Weimerskirch unpubl. data) and speed estimates reported by Spear \& Ainley (1997).

Routes taken to and from wintering areas and accurate departure/return dates could not be determined because birds migrated during equinox periods. We thus separated locations during the non-breeding period, as distinct from the pre-laying exodus and breeding periods, by identifying rapid shifts in latitude and clear changes in activity patterns around April and October (see Fig. S1 and Table S2 in the supplement at www.int-res.com/articles/suppl/m416p267_supp.pdf). Seasonal changes in foraging distribution were investigated by generating fixed kernel density maps using a search radius of $200 \mathrm{~km}$ (Phillips et al. 2006) and a cell size of $0.2^{\circ}$. All individuals were pooled $(\mathrm{n}=24)$ and, considering the inherent error in geolocation, locations over land masses were kept for kernel calculations. Given the higher frequency of light curve interference at different times of year (which leads to range inflation), maps show the 25, 50, 70 and $90 \%$ kernel contours for the non-breeding period, and the 25 and $50 \%$ contours during the breeding and prelaying exodus. Habitats were investigated by determining the oceanographic parameters (bathymetry: $\mathrm{BAT}_{\text {; }}$ sea surface temperature: $\mathrm{SST}_{\text {; }}$ chlorophyll a concentration: CHLA; and their gradients: BATG, SSTG, CHLAG) within kernel utilization distribution contours separately for each stage of the annual cycle.

Activity data analysis. GLS loggers also test for saltwater immersion every $3 \mathrm{~s}$ and store the sum of positive tests at the end of each 10 min block (e.g. a value of 0 indicates that the logger was always dry and a value of 200 indicates that the logger was always wet). The mean percentage of time spent on water was calculated daily and monthly during each stage of the annual cycle to provide information on seasonal variation in foraging behaviour. Time budget calculations excluded periods spent in burrows (prolonged periods of darkness and dry records). Furthermore, we examined number and duration of periods spent on the water (i.e. 'water bouts'), defined as any continuous sequence of 10 min blocks during each of which the bird spent at least $3 \mathrm{~s}$ sitting on the water (Phalan et al. 2007), thus including short periods of flights within the 10 min blocks. This method is likely to underestimate the true number of landings and overestimate their duration; however, Phalan et al. (2007) found a close correlation between the number of water bouts and the number of landings estimated using high resolution wet/dry loggers. Daylight and darkness periods were assessed using sunset and sunrise times estimated 
from the light signal. We compared activity characteristics between stages, and according to daylight versus darkness using either parametric tests (ANOVAs) or non-parametric tests when variables differed from normal distributions (Kruskal-Wallis or Wilcoxon tests). For activity data, the annual cycle was divided into the relevant stages using fixed dates (non-breeding: 31 March to 1 October; pre-laying exodus: 1 October to 1 December; incubation: 1 December to 15 January; chick rearing: 15 January to 31 March).

Satellite tracking. In addition, white-chinned petrels were tracked using Argos satellite platform transmitter terminals (PTTs) to obtain more detailed data on distribution and habitat associations during the breeding season. Fieldwork was conducted during incubation (16 December 2007 to 9 January 2008) and chick rearing (15 January to 21 February 2006). Burrows were marked with wooden stakes and checked regularly to detect shifts in parental attendance and to equip/retrieve devices at the start/end of foraging trips. The 7 individuals tracked during incubation were equipped with battery-powered PTTs working in continuous mode. During the chick-rearing period, 8 individuals were equipped with PTTs powered by battery and working in continuous mode, and 6 individuals with PTTs recharged using a solar panel and a duty cycle of $12 \mathrm{~h} \mathrm{ON}$ and $24 \mathrm{~h}$ OFF. Transmitters were attached to the back feathers using TESA ${ }^{\circledR}$ tape and weighed 18 , 20 or $30 \mathrm{~g}$, which corresponded to 1.6 to $2.9 \%$ of bird body mass. Previous studies conducted on whitechinned petrel at Crozet Island demonstrated that the equipment increased long trip durations (Catard et al. 2000). As time intervals between transmissions varied greatly (range: 1 to $179 \mathrm{~min}$ ), locations were resampled at $30 \mathrm{~min}$ intervals and filtered in order to remove unrealistic positions using the speed-distance-angle (sda) filter developed by Freitas et al. (2008), without constraint on turning angle and based on a maximum mean velocity of $20 \mathrm{~m} \mathrm{~s}^{-1}$ (Spear \& Ainley 1997). We defined outward/inward commuting journeys as periods where birds were flying rapidly in direct routes between their foraging grounds and the colony. Comparisons of trips parameters (with the exception of trip duration) were only made on birds equipped with battery-powered PTTs for which we had continuous data. ANOVAs were used to compare trip characteristics between stages and short/long trips.

Modelling habitat use. We focused on the breeding season and used a hierarchical modelling approach to relate oceanographic variables to residence times estimated via Argos data. Residence time was defined as the proportion of time spent by each bird within a $0.25^{\circ} \times 0.25^{\circ}$ cell. We postulate that a bird actively exploiting a prey patch would spend more time in a certain area than when commuting between foraging patches (Area Restricted Search; Kareiva \& Odell 1987). Residence time was calculated using the tripGrid function in $\mathrm{R}$, which resamples each individual track at a higher temporal resolution by linear interpolation (every $60 \mathrm{~s}$ ) and calculates the time spent in each spatial unit. Then, we assigned the corresponding percentage of time spent in relation to the total trip duration. We kept the estimated percentage of time spent calculated from linear interpolation of the tracks during the OFF-period of the solar PTTs. Ultimately, environmental data (see 'Oceanographic data' below) were temporally and spatially matched to this index of spatial usage at the same spatial scale. Long foraging trips performed during incubation and chick rearing were modelled separately. Short trips (range $=4$ to $78 \mathrm{~h}$ ) were excluded because birds probably used different oceanographic cues when foraging on the Kerguelen continental shelf, and trip durations were in any case too short to model habitat use using the monthly composite data on oceanography that were available.

Environmental variables were selected depending on their biological relevance and availability in the study area (52 to $102^{\circ} \mathrm{E}, 45$ to $66^{\circ} \mathrm{S}$ ). We selected both fixed (BAT) and dynamic variables (SST, SSTG, CHLA, CHLAG and distance to daily sea-ice limit, DIST-ICE; see 'Oceanographic data' for details), because they are likely to influence foraging behaviour. These explanatory variables were standardised (centered and scaled) to improve algorithm convergence and scale the range of the predictors. We checked for colinearity by calculating all pairwise Spearman rank correlation coefficients $\left(\mathrm{r}_{\mathrm{S}}\right)$. When pairs of predictor variables were strongly correlated $\left(\left|r_{S}\right|>0.6\right)$, we ran 2 univariate models with each of these predictors and selected the predictor that led to the lowest Akaike Information Criteria (AIC) (Burnham \& Anderson 2002). We used linear mixed models with the log-transformed percentage of time spent as response variable, and non-correlated oceanographic parameters as explanatory variables. Models were fitted with a Gaussian error distribution and an identity link function. We included individual identity as a random intercept term (during incubation) and trip nested within individual (during chick rearing) to account for the hierarchical structure of the data (Bolker et al. 2009). Non-independence of the error due to spatial autocorrelation was accounted for by adding an autoregressive term (Dormann et al. 2007). We tested multiple autocorrelation structures and selected the one that provided the lowest AIC and best fitted the experimental variogram (Zuur et al. 2009). An exponential correlation structure was thereby selected. We performed all possible linear combinations of explanatory variables and ranked the models based on their AIC values. We then calculated the Akaike weight $\left(w_{i}\right)$ for each model, which represents 
the relative likelihood of candidate models (Burnham \& Anderson 2002). Predictive performances of the best models were assessed by cross-validation. In each simulation ( $\mathrm{n}=1000)$, models were fitted to a training dataset ( $70 \%$ of each trip, selected randomly) and the predictive performance was assessed by comparing observed and predicted time spent of the test dataset (remaining $30 \%$ ). We used Pearson correlation coefficients to assess model predictive performance for each simulation. Ultimately, we mapped the predicted spatial distribution of foraging habitat during both incubation (December 2007) and chick rearing (January 2006) within a spatial extent in accordance with the observed range of long trips performed by white-chinned petrels. The standard deviation of the random intercept terms in the models indicated the level of inter- and/or intraindividual variability. Predictions were made for each trip and then averaged to take into account interand/or intra-individual variability and so draw inferences at the population level.

Oceanographic data. BAT was retrieved from the ETOPO2v2 database at a spatial resolution of $0.033^{\circ}$. SST (NOAA POES AVHRR GAC $0.1^{\circ}$ ) and CHLA (Aqua MODIS NPP $0.05^{\circ}$ ) were obtained using the Xtractomatic routine (http://coastwatch.pfel.noaa.gov/ xtracto/), allowing data extraction from BloomWatch website (http://coastwatch.pfel.noaa.gov/coastwatch/ CWBrowserWW360.jsp). As these environmental variables were not available at the same spatial resolution, we aggregated cells to match a standard grid of $0.25^{\circ}$ cell size. Cloud cover prevented use of weekly data; we thus created our own monthly composite grids by averaging the 4 wk centred at the middle date for each track. Additionally, we calculated spatial gradients: BATG, SSTG and CHLAG, respectively. Satellite-based observations of sea ice (resolution: $25 \mathrm{~km}$ ) were obtained from the National Snow and Ice Data Center (http://nsidc.org/data/docs/daac/nsidc 0051_gsfc_seaice.gd.html; Cavalieri et al. 1996). We used ArcGIS 9.2 (ESRI) to transform sea-ice concentration (SIC) data from the NSIDC's polar stereographic projection into a geographic coordinate system (WGS84). The sea-ice edge is usually defined as the transition region where sea ice covers more than $15 \%$ of the ocean surface (Zwally et al. 2002). Thus, we calculated the sea-ice edge as the maximum latitude of the $>15 \%$ SIC and used a loess filter to create a smooth contour representing this continuous feature. Given the dynamic nature of sea-ice extent during the austral summer, we used daily SIC to identify the sea-ice edge and calculate the distance between each centroid of the grid cell and this limit (DIST-ICE). Moreover, we matched daily bird locations with concurrent daily SIC to quantify associations with pack ice. The general positions of most fronts and the Southern Boundary of the Antarctic Circumpolar Current (SB-ACC) were provided by Orsi et al. (1995) and Harris \& Orsi (2001, updated 2006), and that of the polar front was provided by Moore et al. (1999). Sea surface height and eddy kinetic energy are known to influence seabird foraging distributions ( $\mathrm{Nel}$ et al. 2001), but they were not available south of $62^{\circ} \mathrm{S}$, where white-chinned petrels spend most of their time, and hence could not be included in our models.

\section{RESULTS}

\section{Seasonal variation in foraging grounds}

White-chinned petrels tracked with GLS loggers showed a clear separation in foraging grounds during the breeding and non-breeding seasons, and pre-laying exodus (Fig. 1). They utilised 3 distinct waters masses with contrasting SST depending on the period: neritic subtropical upwelling zone off South Africa in winter $\left(14\right.$ to $\left.16^{\circ} \mathrm{C}\right)$, oceanic subtropical $\left(12\right.$ to $\left.15^{\circ} \mathrm{C}\right)$ and subantarctic waters $\left(6\right.$ to $\left.12^{\circ} \mathrm{C}\right)$ during the prelaying exodus, and Antarctic/subantarctic waters $\left(\sim 1\right.$ to $\left.5^{\circ} \mathrm{C}\right)$ during breeding. During the pre-laying exodus (October), white-chinned petrels dispersed widely, exploiting mainly subtropical and subantarctic waters of the Indian Ocean (Fig. 1). Five individuals returned to the Benguela Current system and 3 others headed towards the western coast of Australia. As birds migrated during the equinox periods ( 2 to $3 \mathrm{wk}$ around 21 March and 22 September), we were not able to describe migration pathways or individual migration schedules. However, based on the rapid shift in activity patterns, mean estimated dates of departure and arrival from breeding sites were 7 April and 25 September, respectively. Overall, birds travelled a minimum distance of $15000 \mathrm{~km}$ during the non-breeding period. All birds migrated to neritic waters off South Africa and Namibia (Benguela Current) during the non-breeding period (April to October) and shifted to forage in subantarctic waters surrounding Kerguelen Island, and Antarctic waters, during the breeding period (Fig. 1). In both years, all tracked individuals wintered in the Benguela region off southwest Africa, with the exception of one bird that wintered off southeast Africa (Agulhas Current) in 2008. The 3 individuals equipped during both years showed fidelity to their wintering grounds. Interestingly, some light peaks were observed during the night for several individuals during the winter months, suggesting the presence of artificial light, potentially from fishing vessels. The contours of the $90 \%$ kernel density distributions encompassed a large area from $5^{\circ} \mathrm{S}$ to $40^{\circ} \mathrm{S}$ in winter, but the core areas ( $25 \%$ contours) delimited more 


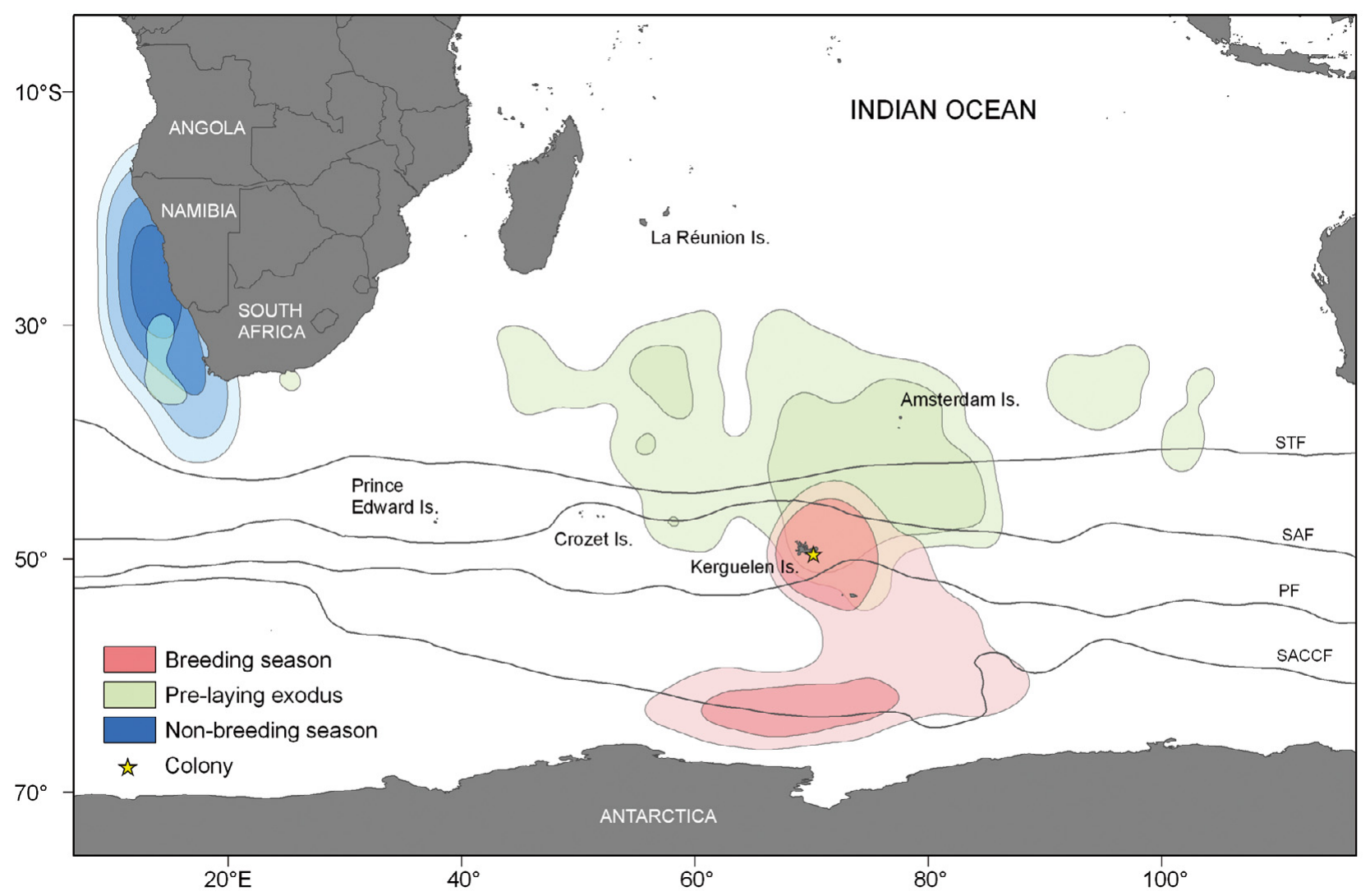

Fig. 1. Procellaria aequinoctialis. Density distributions of white-chinned petrels ( $\mathrm{n}=26$ birds, 4068 estimated locations) from Kerguelen Island during the austral winter (non-breeding period), summer (breeding period) and pre-laying exodus in 2006 and 2008. Density contours encompass 25 to $90 \%$ of the total winter distribution, and 25 to $50 \%$ of the summer and exodus distributions. Frontal structures delimit 4 distinct biogeographic domains: subtropical waters north of the Subtropical Front (STF), the convergence zone between the STF and the Subantarctic Front (SAF), subantarctic waters between the SAF and the Polar Front

(PF), and Antarctic waters south of the PF. SACCF: Southern Antarctic Circumpolar Current Front (Harris \& Orsi 2001)

specifically the coastal upwelling zone of the Benguela Current and were characterized by cold upwelling (SST $\sim 16^{\circ} \mathrm{C}$ ) and high levels of productivity (Figs. 2 \& 3). CHLA and all gradients (BATG, SSTG and CHLAG) were greater in core than peripheral areas, whereas mean depth was much lower $(500 \mathrm{~m})$, corresponding to the continental shelf (Fig. 2). Habitat preferences were for areas of high primary productivity (CHLA and CHLAG) and SSTG during the breeding and nonbreeding seasons, whereas birds were dispersed in less productive waters during the pre-laying exodus (Fig. 2).

\section{Seasonal and daily variations in activity patterns}

The seasonal shift in foraging areas was associated with a change in flight activity (Fig. 4). White-chinned petrels spent more time sitting on the water during the non-breeding period (Table 1) than during the pre- laying exodus $\left(F_{1,40}=398.9, \mathrm{p}<0.001\right)$ and breeding periods $\left(F_{1,36}=235.2, \mathrm{p}<0.001\right.$ and $F_{1,40}=648.8, \mathrm{p}<$ 0.001 for incubation and chick rearing, respectively). Moreover, there were significant differences in the number and duration of bouts spent on the water between the non-breeding and breeding periods $(\mathrm{p}<$ 0.001). During the non-breeding period, bouts on the water were fewer and, on average, longer, than during breeding (Table 1). Birds rearing chicks spent less time on the water than incubating birds $\left(F_{1,36}=21.9, \mathrm{p}<\right.$ 0.001 ). We found no differences in the proportions of time spent on the water in daylight and darkness except during chick rearing (Wilcoxon rank sum test, $W=116.0, \mathrm{p}<0.01$ ), when birds spent more time on water during daylight (Table 1).

Diel activity revealed contrasting seasonal patterns (Fig. 5). All birds tracked over the Benguela Current in winter exhibited the same typical daily pattern: they increased their flight activity at dawn and dusk (Fig. 5a). In contrast, there were no typical daily 

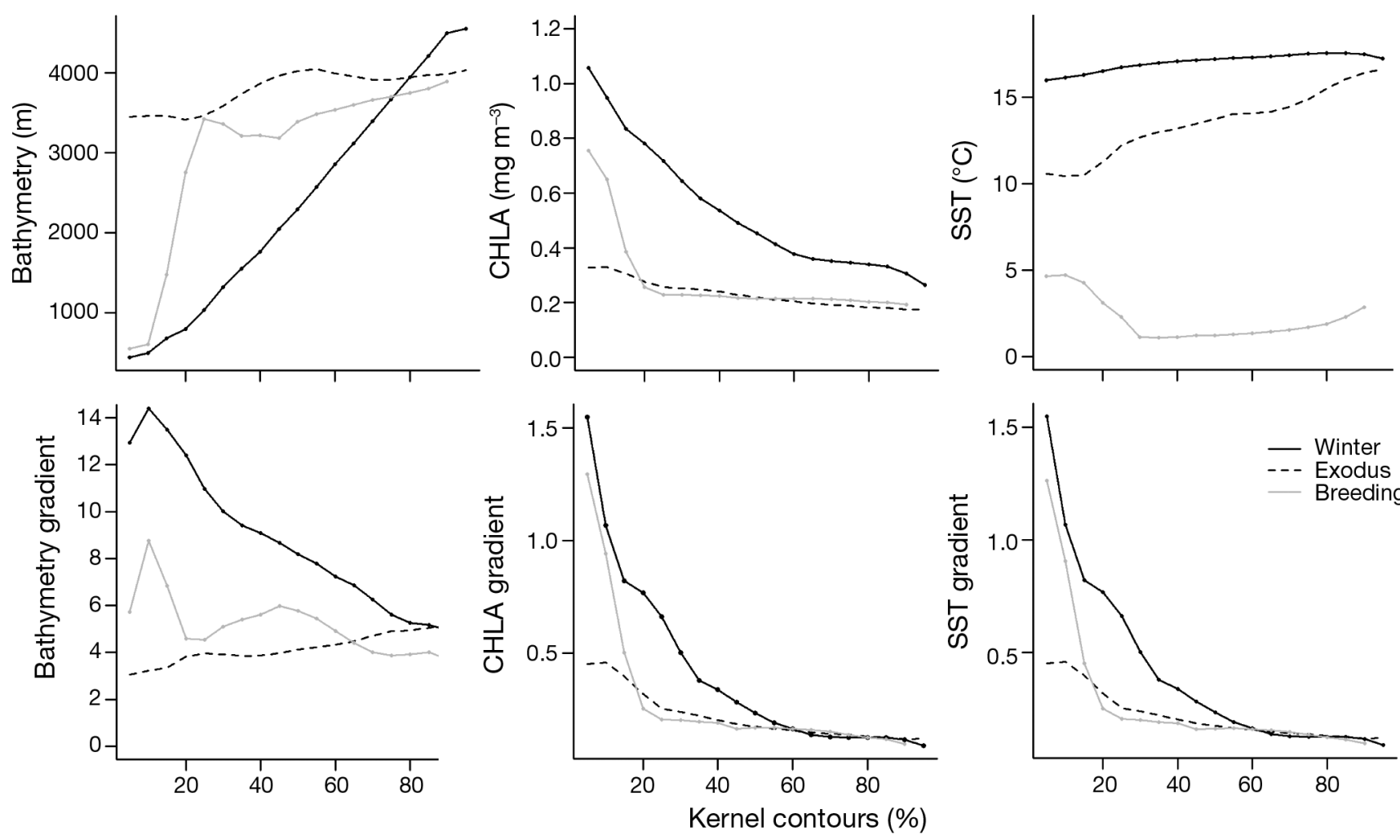

Fig. 2. Procellaria aequinoctialis. Oceanographic conditions in white-chinned petrel ranges (delimited by kernel density contours) during non-breeding (black line), pre-laying exodus (dotted line) and breeding (grey line) periods. Values correspond to medians of the oceanographic parameters. CHLA: chlorophyll a concentration; SST: sea surface temperature

activity patterns during the pre-laying exodus and breeding periods (Fig. 5b).

\section{Breeding foraging trips}

A total of 32 foraging trips were recorded by satellite transmitters: 7 long trips from incubating birds and 25 long or short trips from 14 birds rearing chicks (see Table S3 in the supplement for details on PTT deployments; www.int-res.com/articles/suppl/m416p267_supp. pdf). Among the birds equipped during the chick-rearing period, 9 individuals made repeated foraging trips, generally alternating between long and short trips. Not surprisingly, the distance travelled and the maximal ranges differed significantly between short and long trips for adults rearing chicks (Table 2). In contrast, the maximum range and the average flight speed of long foraging trips performed during incubation and chick rearing did not differ significantly $\left(F_{1,19}=0.8, \mathrm{p}>0.05\right.$ and $F_{1,11}=2.2, \mathrm{p}>0.05$, respectively). All birds travelled towards a $50^{\circ}$ longitudinal section along the seaice edge of the Antarctic continent, approximately 1900 $\mathrm{km}$ from the colony. They spent most of the time (76 and $58 \%$ during incubation and chick rearing, respectively) south of $60^{\circ} \mathrm{S}$ within a $500 \mathrm{~km}$ strip along the pack ice. Birds foraged $1^{\circ}$ farther south during the chick-rearing period (up to $66^{\circ} \mathrm{S}$ ) and their longitudinal range was $10^{\circ}$

Table 1. Procellaria aequinoctialis. Summary of activity parameters for each stage of the annual cycle of white-chinned petrels $($ mean $\pm \mathrm{SD})$

\begin{tabular}{|c|c|c|c|c|c|}
\hline & $\begin{array}{l}\text { Time spent } \\
\text { on water (\%) }\end{array}$ & $\begin{array}{c}\text { Duration of } \\
\text { water bouts (min) }\end{array}$ & $\begin{array}{c}\text { Number of } \\
\text { water bouts }\end{array}$ & \multicolumn{2}{|c|}{ Time spent on water (\%) during } \\
\hline Winter & $65.4 \pm 0.8$ & $164.4 \pm 24.1$ & $6.7 \pm 0.8$ & $66.2 \pm 5.4$ & $64.9 \pm 6.8$ \\
\hline Pre-laying exodus & $26.2 \pm 7.3$ & $45.0 \pm 9.3$ & $13.9 \pm 1.8$ & $25.3 \pm 7.7$ & $27.9 \pm 9.8$ \\
\hline Incubation & $32.2 \pm 8.0$ & $57.7 \pm 14.7$ & $12.9 \pm 1.8$ & $33.3 \pm 11.4$ & $28.8 \pm 10.3$ \\
\hline Chick rearing & $21.8 \pm 5.8$ & $41.1 \pm 9.3$ & $13.2 \pm 1.5$ & $24.4 \pm 7.8$ & $18.9 \pm 5.7$ \\
\hline
\end{tabular}




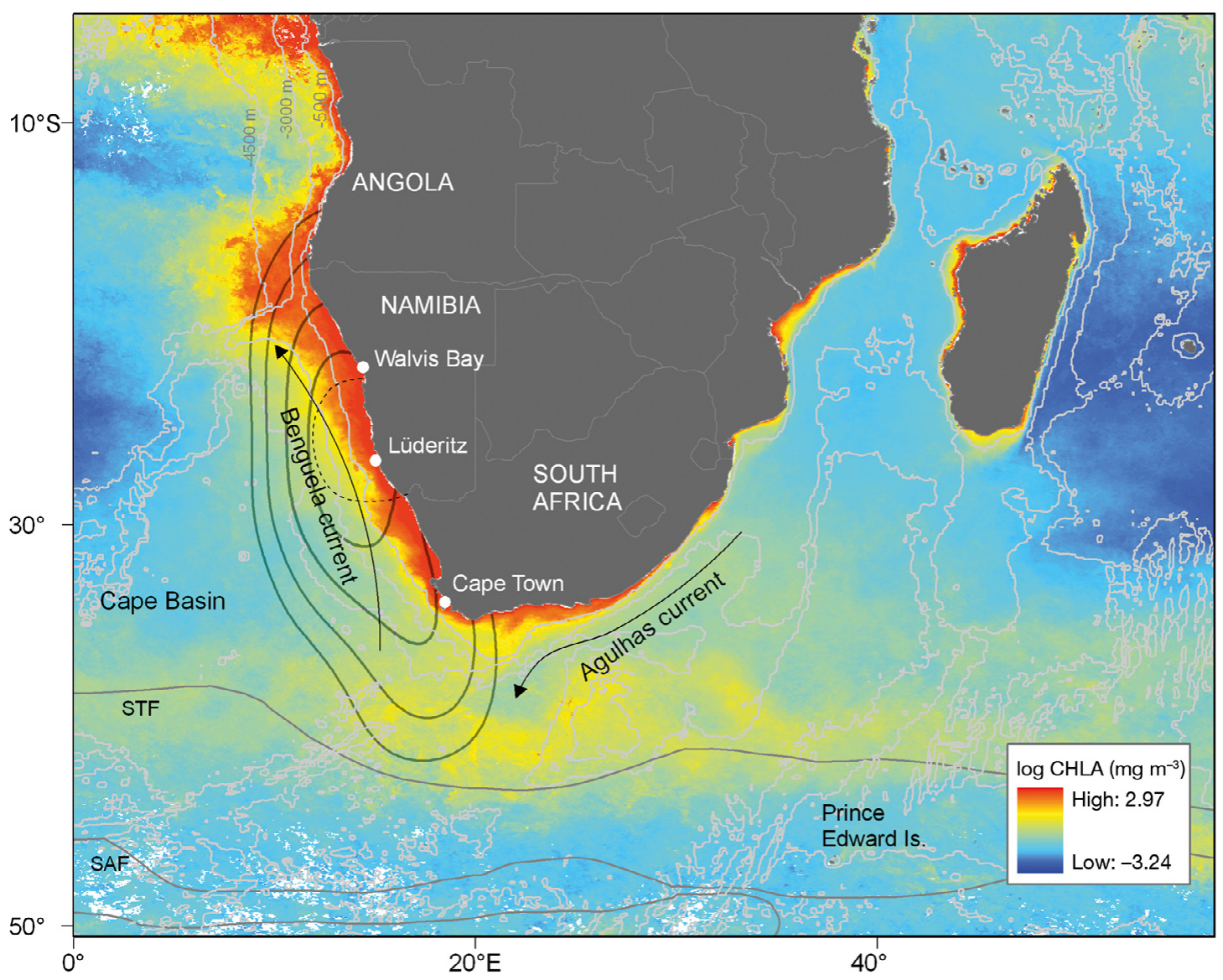

Fig. 3. Procellaria aequinoctialis. White-chinned petrel kernel density distributions $(25,50,70,90 \%$ contours $)$ during the nonbreeding period and mean chlorophyll a concentrations (CHLA) (April to October 2006 and April to October 2008). Dotted line corresponds to the Lüderitz cell within the Benguela upwelling system (from Shannon \& O'Toole 2003). STF: Subtropical Front; SAF: Subantarcic Front

Table 2. Procellaria aequinoctialis. Comparisons of foraging trip parameters (mean \pm $\mathrm{SD}$ ) of white-chinned petrels between breeding stages and long versus short trips during chick rearing. ${ }^{* * *}$ Values were significantly different $(\mathrm{p}<0.001)$ between incubation and chick rearing. -: not calculated

\begin{tabular}{|lccc|}
\hline \multirow{2}{*}{ Type of trip } & \multirow{2}{*}{ Incubation } & \multicolumn{2}{c|}{ Chick rearing } \\
\cline { 3 - 4 } & Long $(\mathrm{n}=7)$ & Long $(\mathrm{n}=15)$ & Short $(\mathrm{n}=10)$ \\
\hline Maximal range $(\mathrm{km})$ & $1965.7 \pm 278.8$ & $1847.6 \pm 170.7$ & $252.8 \pm 238.8$ \\
Distance travelled $(\mathrm{km})$ & $10005.8 \pm 1731.4^{* * *}$ & $6381.8 \pm 1625.5^{* * *}$ & $761.5 \pm 641.1$ \\
Trip duration $(\mathrm{d})$ & $16.3 \pm 1.9^{* * *}$ & $8.9 \pm 1.9^{* * *}$ & $1.07 \pm 0.7$ \\
Mean speed $\left(\mathrm{km} \mathrm{h}^{-1}\right)$ & $26.4 \pm 4.6$ & $29.6 \pm 2.6$ & $29.3 \pm 3.9$ \\
Latitudinal range $\left({ }^{\circ} \mathrm{S}\right)$ & $49.4-64.3$ & $49.0-65.8$ & $56.6-49.3$ \\
Longitudinal range $\left({ }^{\circ} \mathrm{E}\right)$ & $62.3-101.4$ & $52.7-100.8$ & $70.1-81.3$ \\
Outward trip duration $(\mathrm{d})$ & $1.6 \pm 0.5$ & $1.7 \pm 0.6$ & - \\
Inward trip duration $(\mathrm{d})$ & $3.2 \pm 1.5$ & $1.8 \pm 0.7$ & - \\
\hline
\end{tabular}

were no differences in the duration of the outward/ return journeys between stages (Table 2), but incubating birds spent less time commuting during the outward journey $(1.6 \pm$ $0.5 \mathrm{~d})$, following their recent incubation fast, than during the return $\left(3.2 \pm 1.5 \mathrm{~d}, F_{1,12}=6.7, \mathrm{p}<0.05\right)$.

During both breeding stages, birds spent most time within the seasonal ice zone (SIZ), south of $60^{\circ} \mathrm{S}$ (Fig. 6). All incubating birds rapidly headed straight towards the sea-ice edge and then concentrated foraging effort in different patches

wider to the west compared with incubating birds. Trip durations among incubating birds were twice those recorded during chick rearing, and birds travelled greater distances $(\sim 16.3 \pm 1.9 \mathrm{~d}$; $10006 \pm 1731 \mathrm{~km}$ versus $\sim 8.9 \pm 1.9 \mathrm{~d} ; 6382 \pm 1626 \mathrm{~km}$, respectively). There between 61 and $64^{\circ} \mathrm{S}(\sim 10 \mathrm{~d})$. The core area where birds spent maximum time corresponded to offshore waters (isobath $=-4000 \mathrm{~m}$ ) located $\sim 200 \mathrm{~km}$ away from the edge of the pack ice in December (Fig. 6a), where SST was $0^{\circ} \mathrm{C}$ on average. In contrast, birds rearing 

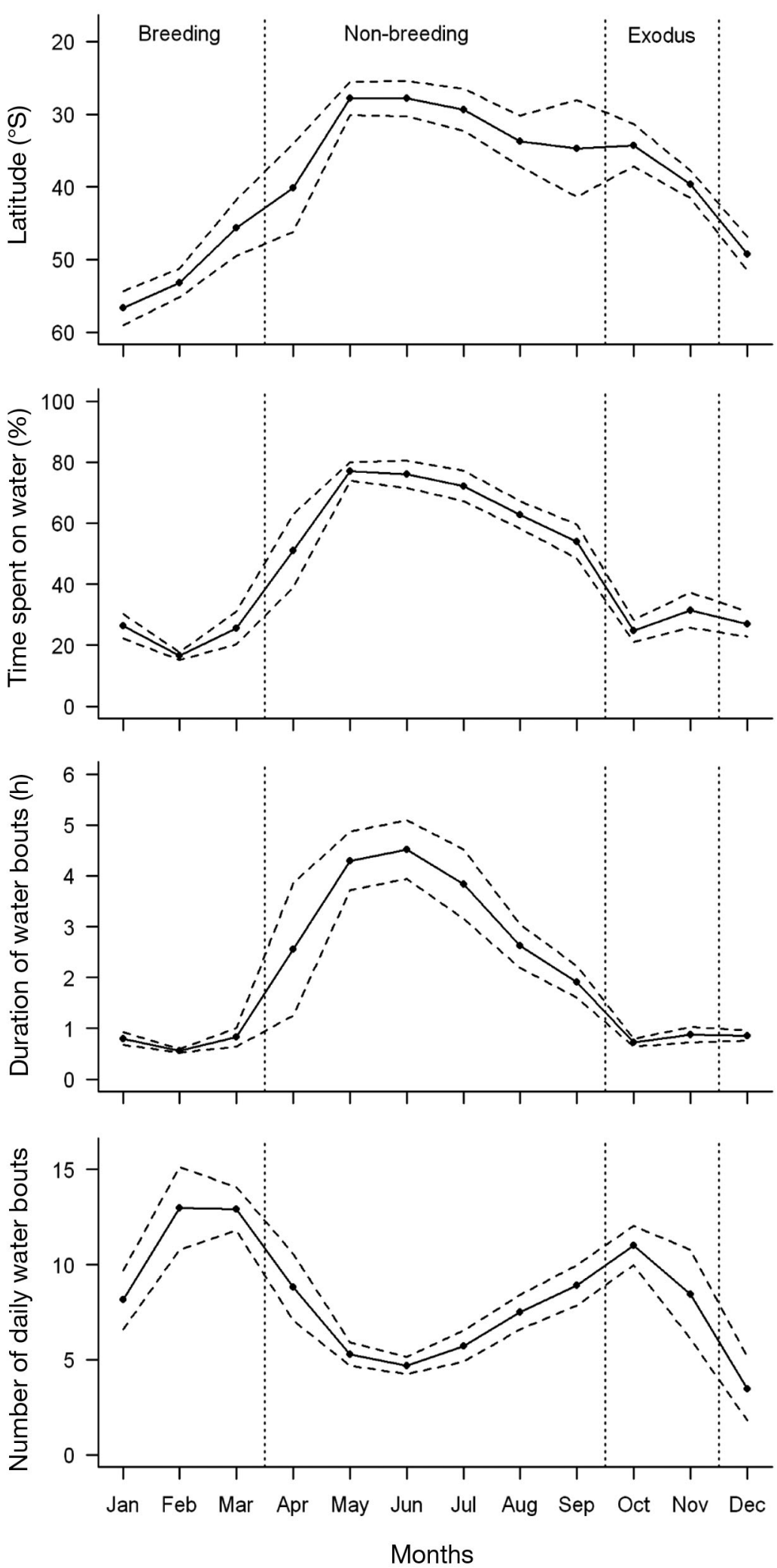

Fig. 4. Procellaria aequinoctialis. Mean annual variation in latitude and activity parameters calculated from 21 geolocator-immersion loggers (solid line) $\pm \mathrm{SD}$ (dashed lines) chicks allocated their time more homogeneously throughout the foraging trips and exploited waters $\sim 300 \mathrm{~km}$ away from the January sea-ice edge (Fig. 6b), where SST was $1^{\circ} \mathrm{C}$ on average. This foraging zone overlies the SB-ACC (Fig. 6).

\section{Modelling of foraging habitat during incubation and chick rearing}

Cross-correlation analysis indicated that SST and DIST-ICE were highly correlated, as were CHLA and GCHLA (see Table S4 in the supplement at www.intres.com/articles/suppl/m416p267_supp. pdf). Univariate ranking led to the removal of CHLA from both models, whereas SST was discarded from the incubation model and DIST-ICE from the chick-rearing model. The models with lowest AIC had relatively high support (Akaike weight, $w_{i} \sim 90 \%$ ) and the $\Delta$ AIC between these models and the second best models were greater than 5 (see Table S5 in the supplement; www. intres.com/articles/suppl/m416p267_supp. pdf). Consequently, we did not apply an averaging procedure but retained the most parsimonious model (Table 3 ). The most important predictors explaining residence time of incubating birds were DIST-ICE and CHLAG (Table 3), indicating that birds foraged preferentially in areas close to the pack ice and characterized by high CHLA variability. During chick rearing, residence time was negatively related to SST and positively associated with CHLAG. SST appeared to be a better predictor of residence time than distance to pack ice later in the breeding season. SSTG was retained by the model selection procedure but its influence on residence time was minor during both stages (Table 3). Model ranking indicated that BAT and BATG had weak influences on spatial allocation of time spent at sea. The standard deviations of the random effects included in the 2 models were relatively small, which suggests low between and within individual variability in response to oceanographic variables (Table 3). Despite the high Akaike weights of the models with the lowest $\mathrm{AIC}$, indicating low parameter uncertain- 


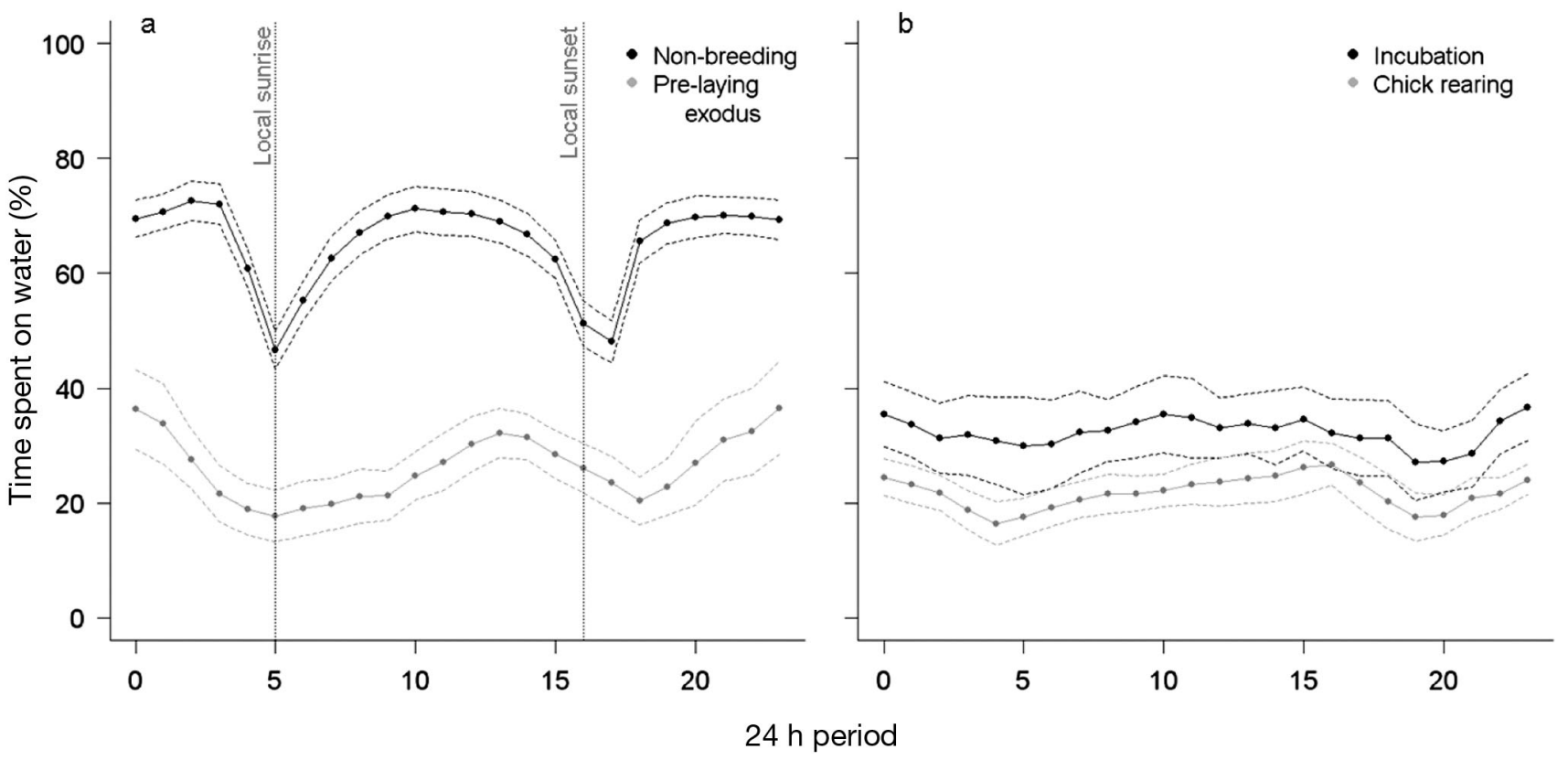

Fig. 5. Procellaria aequinoctialis. Diel variation in white-chinned petrel activity patterns during (a) the non-breeding period and pre-laying exodus, and (b) incubation and chick rearing. Values are means calculated from 21 geolocator-immersion loggers (solid lines) \pm SD (dotted lines). Timing of sunset/sunrise in (a) refers to winter mean values calculated from light signals between April and October (when birds are in the Benguela region). We could not define these times for other periods given the variability in locations

Table 3. Procellaria aequinoctialis. Coefficient estimates and standard errors for environmental variables included in the best candidate models of white-chinned petrel habitat use during incubation and chick rearing. Coefficients are in logscale because the dependent variable (\% time spent) was logtransformed to meet the requirements of linear modelling. The most important oceanographic variables for each breeding stage are marked in bold, by comparing (absolute) normalized estimated coefficients. SST: sea surface temperature; SSTG: SST gradient; CHLAG: chlorophyll a gradient; DISTICE: distance to summer limit of pack ice; AIC: Akaike Information Criteria; $w_{i}$ : Akaike weight

\begin{tabular}{|c|c|c|}
\hline & \multicolumn{2}{|c|}{ — Time spent $(\%)$} \\
\hline & Incubation & Chick rearing \\
\hline Intercept & $-2.297 \pm 0.048$ & $-1.652 \pm 0.064$ \\
\hline$+\mathrm{SST}$ & - & $-0.085 \pm 0.037$ \\
\hline + SSTG & $0.0005 \pm 0.029$ & $0.0008 \pm 0.018$ \\
\hline + CHLAG & $0.101 \pm 0.034$ & $0.022 \pm 0.026$ \\
\hline + DIST-ICE & $-0.215 \pm 0.041$ & - \\
\hline \multicolumn{3}{|c|}{ SD random intercept: } \\
\hline Individuals & 0.069 & 0.0004 \\
\hline Trips & - & 0.1303 \\
\hline $\mathrm{r}^{2}$ & 0.33 & 0.35 \\
\hline AIC & 8048.46 & 12209.08 \\
\hline$w_{i}(\%)$ & 89.68 & 90.88 \\
\hline \multicolumn{3}{|c|}{ Cross-validation $(\mathrm{n}=1000)-\left(\mathrm{r}^{2}\right.$, mean $\left.\left[\mathrm{CI}_{95 \%}\right]\right)$} \\
\hline $70 \%$ train dataset & $0.29[0.26-0.31]$ & $0.32[0.30-0.33]$ \\
\hline $30 \%$ test dataset & $0.28[0.23-0.33]$ & $0.30[0.26-0.34]$ \\
\hline
\end{tabular}

ties, the cross-validation procedure revealed poor predictive performance $\left(\mathrm{r}^{2}\right.$ test $=0.28$ and 0.30 for incubation and chick rearing, respectively, Table 3). However, the averaged spatial predictions of the percentage of time spent matched well with the observed patterns (Fig. 7). During incubation, white-chinned petrel foraging zones were restricted to a narrow latitudinal strip along the pack ice, and zones of maximal CHLAG (Fig. $7 \mathrm{a})$, whereas during chick rearing, sea ice retreated and SST was the most important predictor leading to much larger potential habitat (Fig. 7b). The habitat model for chick-rearing birds identified a key foraging area - the Kerguelen plateau — which was visited during short trips but not included in the modelling process.

\section{DISCUSSION}

Our study demonstrates that Kerguelen whitechinned petrels forage within highly productive zones throughout the year and suggests that they adapt their foraging strategy and behaviour to seasonal variation in prey availability and energetic demand. Their habitats at-sea ranged from subtropical waters of the Benguela Current system during winter, to the Antarctic seasonal ice zone during breeding. In these regions, prey concentrations are relatively high and predictable 

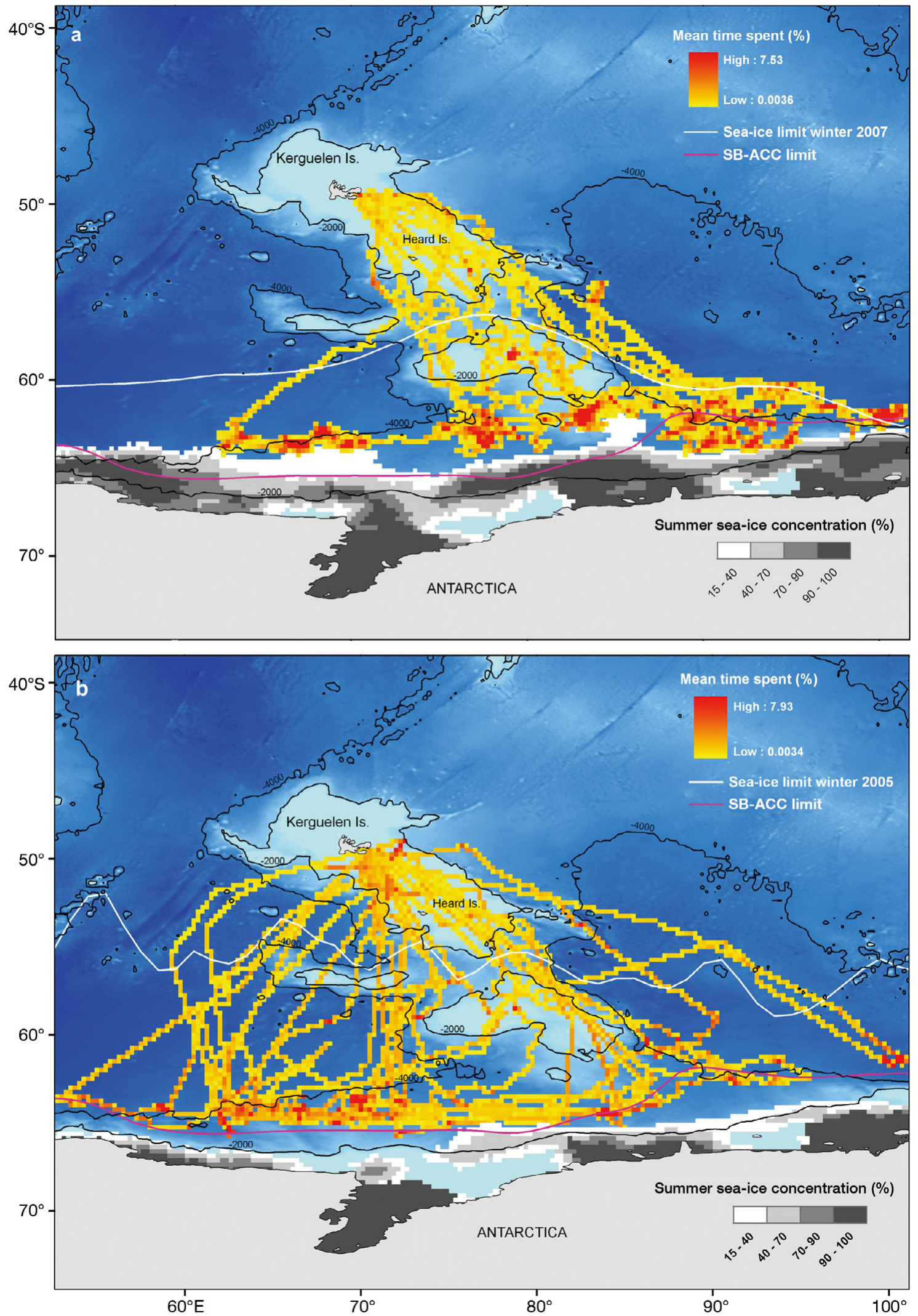

Fig. 6. Procellaria aequinoctialis. Observed habitat use (mean percentage of time spent in each $0.25^{\circ}$ cell) of white-chinned petrels during (a) incubation and (b) chick-rearing periods, and the associated sea-ice concentrations (in December 2007 and January 2006, respectively). The winter sea-ice limit corresponds to the maximum extent of sea ice in September. SB-ACC: Southern Boundary of the Antarctic Circumpolar Current 

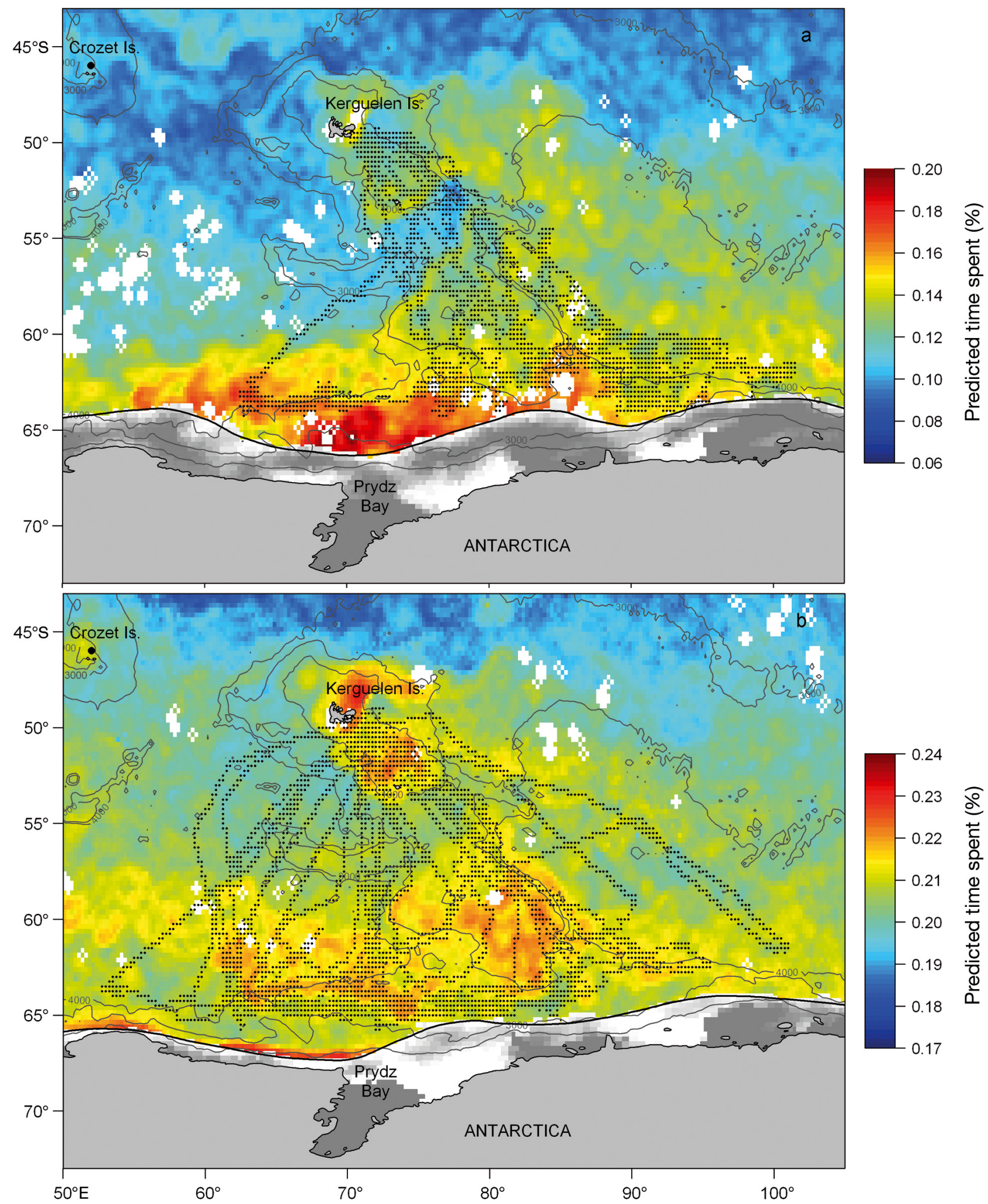

Fig. 7. Procellaria aequinoctialis. Mean spatial predictions of percentage of time spent within each spatial unit obtained by habitat modelling during (a) incubation (December 2007) and (b) chick rearing (January 2006). Dots correspond to locations where proportions of time spent were estimated and used to fit the models 
in time, because they are tied to seasonally forced cold, upwelling waters (Benguela Current) or the sea-ice edge, respectively; both conditions are responsible for elevated levels of primary and secondary production (Longhurst 2007). The seasonal increase in krill abundance associated with the spring/summer retreat of sea ice appears to drive the southerly shift in distribution of white-chinned petrels after egg laying in the southern Indian Ocean.

\section{Foraging in the Benguela Current}

In common with many other albatrosses and petrels, white-chinned petrels migrate from their breeding grounds to exploit rich, productive waters in winter (Phillips et al. 2005, 2006, Shaffer et al. 2006, González-Solís et al. 2007a). Our study revealed that the typical winter migration of white-chinned petrels breeding at Kerguelen Island is to the Benguela Current system, one of the 4 major eastern boundary upwelling systems of the world (Hutchings et al. 2009). Indeed, white-chinned petrel has been reported as one of the most abundant pelagic seabirds over the continental shelf in that region between May and September (Summerhayes et al. 1974), but information on their colony of origin was limited to a few band recoveries (Weimerskirch et al. 1985, Barbraud et al. 2008). Only one individual (3.7\% of birds tracked) wintered in the Agulhas Current. The relatively narrow shelf zone surrounding Namibia and South Africa is characterised by intense upwelling of nutrient-rich deep waters, associated with strong southerly winds and complex current systems (Shannon 1985). This upwelling enhances primary and secondary production, and supports high abundances of epipelagic fishes, notably anchovies Engraulis encrasicolus and sardines Sardinops sagax. At the top of the trophic web, a vast community of predatory fish, seabirds, and marine mammals feed upon these pelagic species, which are also targeted by intensive commercial fisheries throughout the year (Shannon 1985, Grémillet et al. 2008). Several migrant seabirds visit this region in winter, including non-breeding black-browed albatrosses Thalassarche melanophrys from South Georgia (Phillips et al. 2005), and Cory's shearwaters Calonectris diomedea from the Atlantic and Mediterranean Islands (González-Solís et al. 2007a).

Despite the relatively low accuracy of geolocators, which inevitably results in some range inflation (Phillips et al. 2004), and the high proportion of fixes that had to be discarded in our study because of light level interference, the large number of birds tracked nevertheless provided sufficient locations to describe oceanographic habitats reliably. The core area of white-chinned petrel distribution corresponds to the northern region of the Benguela Current off Namibia and encompasses the perennial Lüderitz upwelling cell situated between 26 and $27^{\circ} \mathrm{S}$. This cell is characterized by maximum wind stress from the south and the coldest nutrient-enriched waters along the southwest African coast (Lett et al. 2007). The range of SST in the core white-chinned petrel wintering area (12 to $17^{\circ} \mathrm{C}$ ) corresponds to the zone of maximum productivity between freshly upwelled water $\left(9\right.$ to $\left.11^{\circ} \mathrm{C}\right)$ and the offshore divergence $\left(>19^{\circ} \mathrm{C}\right)$ (Lett et al. 2007). Hence, we also found that white-chinned petrels were associated with high CHLA concentrations and bathymetric gradients. The kernel density distribution indicated that petrels exploit neritic waters over the narrow continental shelf $(<500 \mathrm{~m})$, in agreement with conclusions reached in a recent stable isotope study (Jaeger et al. 2010). Moreover, a previous study conducted by Jackson (1988) reported higher white-chinned petrel densities close to the shelf break (500 m), a bathymetric feature also targeted by longliners and trawlers operating in the region throughout the year (Grémillet et al. 2008). White-chinned petrels are known to attend fishing vessels during both night and day (Ryan \& Moloney 1988) and the peaks of light observed during the night when processing our logger light records indicated night interactions with fishing vessels. Although whitechinned petrels experience high rates of bycatch, particularly in August and September in the southern Benguela (Grantham et al. 2008, Watkins et al. 2008), fishing vessels provide food to seabirds in the form of bait or continuous flow of offal during fish processing (Barnes et al. 1997). Indeed, discards (Cape hake Merluccius capensis and rat-tail Coelorhynchus fasciatus) comprise a high proportion of the diet of whitechinned petrels in the region (Jackson 1988). Local depletion of food resources (anchovies and sardines) by fisheries has had dramatic effects on populations of Cape gannets Morus capensis breeding on the coast of Namibia and Southern Africa (Okes et al. 2009). However, this effect may be less severe for birds that overwinter in the area because they are not central place foragers at that time and, with no spatio-temporal constraints, can move freely to find profitable prey patches. Hence, both local availability of natural food resources and locations of fishing vessels will influence white-chinned petrel distribution (Ryan \& Moloney 1988). Similarly, white-chinned petrels breeding at South Georgia winter in highly productive subtropical waters on the Patagonian Shelf and Humboldt upwelling system off Chile, where they are known to interact a great deal with fisheries (Phillips et al. 2006).

Our study revealed that white-chinned petrels spent a greater proportion of time sitting on the water during the non-breeding period than during the breeding 
period, a behaviour shared with others procellariiforms (Mackley et al. 2010). Interestingly, they sat on the water for longer periods and reduced their number of landings/take-offs during the non-breeding period. We suggest several, non-exclusive hypotheses to explain reduced flight activity during the non-breeding period: (1) lower energy requirement compared to the breeding season, (2) an opportunistic sit-and-wait foraging strategy in highly productive waters, (3) interaction with other marine top predators or fisheries that facilitate foraging (Au \& Pitman 1986, Bartumeus et al. 2010) or (4) a reduced flight ability due to moult. The diel activity pattern of wintering birds revealed a peak in flight activity at dawn and dusk. This accords with observations by Barnes et al. (1997) of an increase in white-chinned petrel foraging activity (flying, diving or competing for food) ca. $2.5 \mathrm{~h}$ prior to sunrise, independent of fishing operations. This observation led to a recommendation that line shooting be completed before this period to reduce bycatch. The diel winter activity pattern was surprisingly consistent among individuals. This synchronization may be enforced by changes in prey availability linked to diel vertical migration of small pelagic schooling fish (Beckley \& van der Lingen 1999), which often move towards the surface during the night in response to similar movement of their prey. This might allow an optimal foraging window for petrels when prey are still accessible and light intensity is great enough to allow visual predation.

\section{Foraging in Antarctic waters}

The breeding period coincides with increased energetic demands when birds need to benefit from predictable resources to maintain their own condition while also provisioning the chick (Weimerskirch 2007). Kernel density distributions and habitat use models highlighted 2 areas of increased utilisation during the breeding season; one corresponding to the continental shelf around Kerguelen Island and the other to Antarctic waters. White-chinned petrels from Kerguelen foraged in subtropical/subantarctic waters during the pre-laying exodus and made long trips to Antarctic waters during both incubation and chick rearing.

This contrasts with white-chinned petrels from Crozet and South Georgia, which exploit mainly subtropical and subantarctic waters during the early breeding season (Benguela Current and Patagonian Shelf, respectively) and shift to Antarctic waters only after chicks hatch (Weimerskirch et al. 1999, Catard et al. 2000, Phillips et al. 2006). Satellite transmitters revealed that adults rearing young performed shorter long trips, but were able to commute rapidly and directly to areas at similar distances to those used during incubation. However, our results suggested that they forage more continuously along the outward portion of the journey than incubating birds, which concentrated their foraging effort at the southernmost latitudes. They targeted the SIZ, where melting sea ice is gradually broken into floes, and foraged almost exclusively in open water $(<1 \%$ of total locations were in pack ice), consistent with at-sea observations in this region (Woehler et al. 2003, 2010). All long trips were performed clockwise, a direction favoured by the eastward winds prevailing south of $60^{\circ} \mathrm{S}$, close to Antarctica (Weimerskirch et al. 2000b).

Habitat models indicated that the distance to the pack ice was an important determinant of whitechinned petrel foraging zones during incubation, whereas SST was the most important factor during chick rearing. The change in the main predictors between the 2 breeding stages resulted in a less extensive foraging zone during incubation than during chick rearing, as highlighted by predictive maps. It may be driven by changes in oceanographic conditions as summer progresses and/or changes in energetic constrains. As summer progresses, sea-ice cover decreases, the SIZ becomes larger, important resources become increasingly available at large spatial scales and birds are forced to increase foraging efficiency to fulfil their breeding obligations. Predictions of spatial usage made during incubation and chick-rearing periods in the same breeding seasons (2005/06 and 2007/08) confirmed that this spatial pattern was consistent and did not result from inter-annual variability in oceanographic parameters. In contrast to winter distribution, petrels did not occur in areas of steep bathymetric gradients, but instead exploited deep, oceanic waters. The linear interpolation of the tracks during the OFFperiod of the solar PTTs may have introduced some noise in the chick-rearing model, because we assumed that birds flew in a straight line at a constant speed between 2 locations separated by several hours. However, model selection performed on a dataset excluding the OFF-period retained the same explanatory variables; the directions of the relationships were similar, and coefficients differed only slightly.

During both stages, birds were associated with the main frontal features of Antarctic waters (i.e. high CHLA and SST variability) characterized by local convergence and prey aggregation (Hunt et al. 1981). The predicted foraging areas matched well with the distribution of Antarctic krill Euphausia superba, a key food resource in the Southern Ocean ecosystem, found south of $59^{\circ} \mathrm{S}$ in our study area (Miquel 1991, Nicol et al. 2000, Jarvis et al. 2010). The analysis of chick diet samples collected during the same period at the same colony confirms the importance of Antarctic krill as 
food resource during long trips towards Antarctica (Delord et al. in press). Indeed, the SIZ supports large concentrations of Antarctic krill that depend on the extent and duration of sea-ice cover, summer phytoplankton blooms, and sea-ice-affiliated algae that promote early adult spawning in spring, and survival of the larvae the following winter (Atkinson et al. 2004). The predictability of krill for foraging petrels may be favoured by its concentration in a few high-density swarms, at scales of tens of metres and larger aggregation within patches at a scale of $\mathrm{km}$ (Atkinson et al. 2008). Moreover, this foraging area overlaps with the SB-ACC, which corresponds to the poleward extent of the Antarctic circumpolar current, considered to be a seasonally predictable and productive foraging location for many marine top predators feeding on krill during the austral summer (Tynan 1998, Nicol et al. 2000). Information on large-scale distribution and abundance of Antarctic krill on a monthly basis would therefore be a useful addition to our models, but unfortunately, such data are currently unavailable. Nevertheless, concurrent diet analyses have indicated that white-chinned petrels also feed on fish, squid and others crustaceans while rearing chicks (Delord et al. in press).

In contrast with behaviour during the non-breeding period, breeding white-chinned petrels spent less time sitting on the water and did not exhibit a distinct diel activity pattern. The absence of a typical diel activity pattern during the pre-laying exodus and breeding stages may be due to the high variation in daylight length depending on the latitude of the foraging grounds (e.g. $>23 \mathrm{~h}$ daylight near Antarctica in January). The high proportion of time in flight is likely to reflect increased energetic demand and higher foraging effort in summer compared to winter (i.e. active search versus sit and wait strategies, respectively). Prolonged summer daylight in Antarctic waters may also explain part of the differences in foraging strategies, potentially making prey available all day long (Phalan et al. 2007). The high frequency of short water bouts indicated that white-chinned petrels were more active during summer and alternated between short periods on water (probably feeding) and longer periods in flight (searching).

\section{Future climate and conservation implications}

White-chinned petrels from Kerguelen Island face different threats depending on the stage of their annual cycle, as they target distinct foraging grounds that are subject to varying anthropogenic pressures. Seabird bycatch by longline fishing vessels and trawlers off South Africa has historically been extremely high, with annual estimates of 33850 birds killed in longline fisheries (Petersen et al. 2007) and 18000 birds killed in interactions with trawlers (Watkins et al. 2008). A considerable proportion of this bycatch consists of white-chinned petrels with an estimated 8000 birds per year in the hake longline fishery in the 1990s (Barnes et al. 1997), and 1500 birds per year in the recent study of trawl mortality (Watkins et al. 2008). Although improved mitigation measures are now in place in South African fisheries (Anonymous 2008), the bycatch threat remains critical for whitechinned petrels. Although bycatch mortality is possibly lower in summer, longline fisheries targeting Patagonian toothfish Dissostichus eleginoides over the Kerguelen Shelf, and more recently Antarctic toothfish D. mawsoni in Antarctic waters, could contribute to additional mortality especially near breeding colonies (Weimerskirch et al. 2000a, Tuck et al. 2003, Delord et al. 2005). Since there is no demographic monitoring for white-chinned petrels breeding at Kerguelen Island, it is impossible to quantify the effect of bycatch on their population dynamics. Nevertheless, given that both bycatch and large-scale climatic phenomena (e.g. El Niño Southern Oscillation, ENSO) contributed to population decline of white-chinned petrels breeding at Crozet (Barbraud et al. 2008), it is possible that birds from Kerguelen Island are similarly affected.

The foraging areas highlighted herein are highly productive and characterized by complex oceanographic processes. The effects of climate change on the Benguela Current system are poorly known, but declines and eastward shifts in pelagic resources observed during the past decades indicate the direction of ongoing changes (Hutchings et al. 2009). The prevailing climate change models predict continued ocean warming, earlier break-up of annual sea ice, and large-scale reduction in overall Antarctic sea-ice cover (Gross 2005). The recent loss of sea ice in the Antarctic Peninsula coincided with a decline in abundance of Antarctic krill (Loeb et al. 1997, Atkinson et al. 2004) - a clear signal of major environmental changes that could occur throughout the Southern Ocean and within our study sector. If krill becomes increasingly scarce, competition will intensify. Moreover, fisheries operating in these highly productive zones negatively affect seabirds by reducing abundance of marine resources and/or causing additional mortality by direct interactions. Although the whitechinned petrel may be less susceptible than other species given its versatility in foraging methods (greater diving ability, capacity to feed during both day and night, and extensive foraging range), they remain one of the most common casualties of fisheries. Habitat modelling provides new insights on the spatial distribution of potential threats and key foraging areas that 
could be incorporated into demographic models to assess their relative influence on population dynamics and to predict future population trends. Given the increasing anthropogenic pressures in this region and evidence of wide-scale population declines of whitechinned petrels, there is little room for complacency.

Acknowledgements. This study was carried out at Kerguelen Island with the logistical and financial support of IPEV (French Polar Institute, Program No. 109 to H.W.). It was also supported by the Syndicat des Armements Réunionnais de Palangriers Congélateurs (SARPC), the Prince Albert II de Monaco Foundation and the French Southern Territories (TAAF). We thank all the fieldworkers involved in logger deployment or recovery: M. Nevoux, A. Jacquet, R. Perdriat, Q. Delorme, A. Knochel, J.-B. Thiebot, J. Nezan, J.-B. Pons. We also thank D. Pinaud for his help and advice on spatial analysis, and V. Lecomte and P. Pinet for their advice on activity data. Some of the data used in this paper were obtained from the Australian Antarctic Data Centre (IDN Node $\mathrm{AMD} / \mathrm{AU}$ ), a part of the Australian Antarctic Division (Commonwealth of Australia). These data are described in the metadata record 'Locations of the various fronts in the Southern Ocean' (Harris \& Orsi 2001, updated 2006). This study is a part of programs REMIGE and GLIDES funded by ANR-Biodiversity (France) and represents a contribution to the British Antarctic Survey Ecosystems Programme.

\section{LITERATURE CITED}

Afanasyev V (2004) A miniature daylight level and activity data recorder for tracking animals over long periods. Mem Natl Inst Polar Res 58:227-233

Anonymous (2008). National plan of action for reducing the incidental catch of seabirds in longline fisheries. Department of Environmental Affairs and Tourism, Republic of South Africa, Pretoria

Atkinson A, Siegel V, Pakhomov E, Rothery P (2004) Longterm decline in krill stock and increase in salps within the Southern Ocean. Nature 432:100-103

Atkinson A, Siegel V, Pakhomov EA, Rothery P and others (2008) Oceanic circumpolar habitats of Antarctic krill. Mar Ecol Prog Ser 362:1-23

Au DWK, Pitman RL (1986) Seabird interactions with dolphins and tuna in the eastern tropical Pacific. Condor 88: 304-317

Barbraud C, Marteau C, Ridoux V, Delord K, Weimerskirch H (2008) Demographic response of a population of whitechinned petrels Procellaria aequinoctialis to climate and longline fishery bycatch. J Appl Ecol 45:1460-1467

Barbraud C, Delord K, Marteau C, Weimerskirch H (2009) Estimates of population size of white-chinned petrels and grey petrels at Kerguelen Islands and sensitivity to fisheries. Anim Conserv 12:258-265

Barnes KN, Ryan PG, Boix-Hinzen C (1997) The impact of the hake Merluccius spp. longline fishery off South Africa on procellariiform seabirds. Biol Conserv 82:227-234

Bartumeus F, Giuggioli L, Louzao M, Bretagnolle V, Oro D, Levin S (2010) Fishery discards distort seabird search patterns. Curr Biol 20:215-222

Beckley L, van der Lingen C (1999) Biology, fishery and management of sardines (Sardinops sagax) in southern African waters. Mar Freshw Res 50:955-978

Berrow SD, Croxall JP, Grant SD (2000) Status of white- chinned petrels Procellaria aequinoctialis Linnaeus 1758, at Bird Island, South Georgia. Antarct Sci 12:399-405

BirdLife International (2010) Species factsheet: Procellaria aequinoctialis. http://www.birdlife.org

Bolker BM, Brooks ME, Clark CJ, Geange SW, Poulsen JR, Stevens MH, White JS (2009) Generalized linear mixed models: a practical guide for ecology and evolution. Trends Ecol Evol 24:127-135

Bost CA, Thiebot JB, Pinaud D, Cherel Y, Trathan PN (2009) Where do penguins go during the inter-breeding period? Using geolocation to track the winter dispersion of the macaroni penguin. Biol Lett 5:473-476

Burnham KP, Anderson DR (2002) Model selection and multimodel inference: a practical information-theoretic approach. Springer Verlag, New York, NY

Cañadas A, Sagarminaga R, De Stephanis R, Urquiola E, Hammond PS (2005) Habitat preference modelling as a conservation tool: proposals for marine protected areas for cetaceans in southern Spanish waters. Aquat Conserv: Mar Freshw Ecosyst 15:495-521

Catard A, Weimerskirch H, Cherel Y (2000) Exploitation of distant Antarctic waters and close shelf-break waters by white-chinned petrels rearing chicks. Mar Ecol Prog Ser 194:249-261

Cavalieri D, Parkinson C, Gloersen P, Zwally HJ (1996, updated 2008) Sea ice concentrations from Nimbus-7 SMMR and DMSP SSM/I passive microwave data (list dates of temporal coverage used). Digital media. National Snow and Ice Data Center, Boulder, CO. http://nsidc.org/ data/docs/daac/nsidc0051_gsfc_seaice.gd.html

Delord K, Gasco N, Weimerskirch H, Barbraud C, Micol T (2005) Seabird mortality in the Patagonian toothfish longline fishery around Crozet and Kerguelen Islands, 20012003. CCAMLR Sci 12:53-80

Delord K, Cotté C, Péron C, Marteau C and others (in press) At-sea distribution and diet of an endangered top predator: links of white-chinned petrels with commercial longline fisheries. Endang Species Res doi:10.3354/esr00309

> Dormann CF, McPherson JM, Araujo MB, Bivand R and others (2007) Methods to account for spatial autocorrelation in the analysis of species distributional data: a review. Ecography 30:609-628

> Egevang C, Stenhouse IJ, Phillips RA, Petersen A, Fox JW, Silk JRD (2010) Tracking of Arctic terns Sterna paradisaea reveals longest animal migration. Proc Natl Acad Sci USA 107:2078-2081

Freitas C, Lydersen C, Fedak MA, Kovacs KM (2008) A simple new algorithm to filter marine mammal Argos locations. Mar Mamm Sci 24:315-325

González-Solís J, Croxall JP, Oro D, Ruiz X (2007a) Transequatorial migration and mixing in the wintering areas of a pelagic seabird. Front Ecol Environ 5:297-301

> González-Solís J, Croxall JP, Afanasyev V (2007b) Offshore spatial segregation in giant petrels Macronectes spp.: differences between species, sexes and seasons. Aquat Conserv: Mar Freshw Ecosyst 17:S22-S36

> Grantham HS, Petersen SL, Possingham H (2008) Reducing bycatch in the South African pelagic longline fishery: the utility of different approaches to fisheries closures. Endang Species Res 5:291-299

Green JA, Boyd IL, Woakes AJ, Warren NL, Butler PJ (2009) Evaluating the prudence of parents: daily energy expenditure throughout the annual cycle of a free-ranging bird, the macaroni penguin Eudyptes chrysolophus. J Avian Biol 40:529-538

> Grémillet D, Pichegru L, Kuntz G, Woakes AG, Wilkinson S, Crawford RJM, Ryan PG (2008) A junk-food hypothesis for 
gannets feeding on fishery waste. Proc Biol Sci 275: $1149-1156$

Gross L (2005) As the Antarctic ice pack recedes, a fragile ecosystem hangs in the balance. PLoS Biol 3:e224

Harris U, Orsi A (2001, updated 2006) Locations of the various fronts in the Southern Ocean. Australian Antarctic Data Centre - CAASM Metadata. http://data.aad.gov.au/ aadc/metadata/metadata_redirect.cfm?md=AMD/AU/ southern_ocean_fronts

Hunt GLJ, Gould PJ, Forsell DJ, Peterson HJ (1981) Pelagic distribution of marine birds in the eastern Bering Sea. In: Hood DW, Caulder JA (eds) The eastern Bering Sea shelf: oceanography and resources. National Oceanic \& Atmospheric Administration, Washington, DC, p 689-717

Hutchings L, van der Lingen CD, Shannon LJ, Crawford RJM and others (2009) The Benguela Current: an ecosystem of four components. Prog Oceanogr 83:15-32

> Hyrenbach KD, Fernandez P, Anderson DJ (2002) Oceanographic habitats of two sympatric North Pacific albatrosses during the breeding season. Mar Ecol Prog Ser 233: 283-301

> Jackson S (1988) Diets of the white-chinned petrel and sooty shearwater in the southern Benguela region, South Africa. Condor 90:20-28

> Jaeger A, Connan M, Richard P, Cherel Y (2010) Use of stable isotopes to quantify seasonal changes of trophic niche and levels of population and individual specialisation in seabirds. Mar Ecol Prog Ser 401:269-277

> Jarvis T, Kelly N, Kawaguchi S, van Wijk E, Nicol S (2010) Acoustic characterisation of the broad-scale distribution and abundance of Antarctic krill (Euphausia superba) off East Antarctica $\left(30-80^{\circ} \mathrm{E}\right)$ in January-March 2006. DeepSea Res II 57:916-933

Jouventin P, Mougin JL, Stahl JC, Weimerskirch H (1985) Comparative biology of the burrowing petrels of the Crozet Islands. Notornis 32:157-220

- Kareiva P, Odell G (1987) Swarms of predators exhibit 'preytaxis' if individual predators use area-restricted search. Am Nat 130:233-270

Lett C, Veitch J, van der Lingen CD, Hutchings L (2007) Assessment of an environmental barrier to transport of ichthyoplankton from the southern to the northern Benguela ecosystems. Mar Ecol Prog Ser 347:247-259

> Loeb V, Siegel V, Holm-Hansen O, Hewitt R, Fraser W, Trivelpiece W, Trivelpiece S (1997) Effects of sea-ice extent and krill or salp dominance on the Antarctic food web. Nature 387:897-900

Longhurst A (2007) Ecological geography of the sea. Elsevier Academic Press, Oxford

Louzao M, Hyrenbach KD, Arcos JM, Abello P, De Sola LG, Oro D (2006) Oceanographic habitat of an endangered Mediterranean procellariiform: implications for marine protected areas. Ecol Appl 16:1683-1695

Louzao M, Bécares J, Rodríguez B, Hyrenbach KD, Ruiz A, Arcos JM (2009) Combining vessel-based surveys and tracking data to identify key marine areas for seabirds. Mar Ecol Prog Ser 391:183-197

Mackley EK, Phillips RA, Silk JRD, Wakefield ED, Afanasyev V, Fox JW, Furness RW (2010) Free as a bird? activity patterns of albatrosses during the nonbreeding period. Mar Ecol Prog Ser 406:291-303

> Martin AR, Poncet S, Barbraud C, Foster E, Fretwell P, Rothery P (2009) The white-chinned petrel (Procellaria aequinoctialis) on South Georgia: population size, distribution and global significance. Polar Biol 32:655-661

> McConnell BJ, Chambers C, Fedak MA (1992) Foraging ecology of southern elephant seals in relation to the bathyme- try and productivity of the Southern Ocean. Antarct Sci 4: 393-398

Miquel JC (1991) Distribution and abundance of post-larval krill (Euphausia superba Dana) near Prydz Bay in summer with reference to environmental conditions. Antarct Sci 3:279-292

Moore JK, Abbott MR, Richman JG (1999) Location and dynamics of the Antarctic Polar Front from satellite sea surface temperature data. J Geophys Res 104:3059-3073

Mougin JL (1968) Etude écologique de quatre espèces de pétrels Antarctiques. Oiseau 38:1-52

Nel DC, Lutjeharms JRE, Pakhomov EA, Ansorge IJ, Ryan PG, Klages NTW (2001) Exploitation of mesoscale oceanographic features by grey-headed albatross Thalassarche chrysostoma in the southern Indian Ocean. Mar Ecol Prog Ser 217:15-26

Nel DC, Ryan PG, Crawford RJM, Cooper J, Huyser OAW (2002) Population trends of albatrosses and petrels at subAntarctic Marion Island. Polar Biol 25:81-89

Nicol S, Pauly T, Bindoff NL, Wright SW and others (2000) Ocean circulation off east Antarctica affects ecosystem structure and sea-ice extent. Nature 406:504-507

> Okes NC, Hockey PAR, Pichegru L, van der Lingen CD, Crawford RJM, Grémillet D (2009) Competition for shifting resources in the southern Benguela upwelling: Seabirds versus purse-seine fisheries. Biol Conserv 142: 2361-2368

Orsi AH, Whitworth T III, Nowlin WD Jr (1995) On the meridional extent and fronts of the Antarctic Circumpolar Current. Deep-Sea Res 42:641-673

Péron C, Authier M, Barbraud C, Delord K, Besson D, Weimerskirch H (2010) Inter-decadal changes in at-sea distribution and abundance of subantarctic seabirds along a latitudinal gradient in the Southern Indian Ocean. Glob Change Biol 16:1895-1909

Petersen SL, Honig MB, Nel DC (2007) The impact of longline fisheries on seabirds in the Benguela Current large marine ecosystem. In: Petersen S, Nel D, Omardien A (eds) Towards an ecosystem approach to longline fisheries in the Benguela: an assessement of impacts on seabirds, sea turtles and sharks. WWF South Africa Report Series2007/Marine/001. WWF South Africa, Cape Town, p 9-31

> Phalan B, Phillips RA, Silk JRD, Afanasyev V and others (2007) Foraging behaviour of four albatross species by night and day. Mar Ecol Prog Ser 340:271-286

> Phillips RA, Xavier JC, Croxall JP (2003) Effects of satellite transmitters on albatrosses and petrels. Auk 120: 1082-1090

Phillips RA, Silk JRD, Croxall JP, Afanasyev V, Briggs DR (2004) Accuracy of geolocation estimates for flying seabirds. Mar Ecol Prog Ser 266:265-272

Phillips RA, Silk JRD, Croxall JP, Afanasyev V, Bennett VJ (2005) Summer distribution and migration of nonbreeding albatrosses: individual consistencies and implications for conservation. Ecology 86:2386-2396

Phillips RA, Silk JRD, Croxall JP, Afanasyev V (2006) Yearround distribution of white-chinned petrels from South Georgia: relationships with oceanography and fisheries. Biol Conserv 129:336-347

Phillips RA, Catry P, Silk JRD, Bearhop S, McGill R, Afanasyev V, Strange IJ (2007) Movements, winter distribution and activity patterns of Falkland and brown skuas: insights from loggers and isotopes. Mar Ecol Prog Ser 345:281-291

> Pinaud D, Weimerskirch H (2007) At-sea distribution and scale-dependent foraging behaviour of petrels and albatrosses: a comparative study. J Anim Ecol 76:9-19 
Polovina JJ, Howell E, Kobayashi DR, Seki MP (2001) The transition zone chlorophyll front, a dynamic global feature defining migration and forage habitat for marine resources. Prog Oceanogr 49:469-483

R Development Core Team (2009) R: a language and environment for statistical computing. R Foundation for Statistical Computing, Vienna

Rolland V, Barbraud C, Weimerskirch H (2008) Combined effects of fisheries and climate on a migratory long-lived marine predator. J Appl Ecol 45:4-13

Ryan PG, Moloney CL (1988) Effect of trawling on bird and seal distributions in the southern Benguela region. Mar Ecol Prog Ser 45:1-11

Shaffer SA, Tremblay Y, Weimerskirch H, Scott D and others (2006) Migratory shearwaters integrate oceanic resources across the Pacific Ocean in an endless summer. Proc Natl Acad Sci USA 103:12799-12802

Shannon LV (1985) The Benguela ecosystem I: evolution of the Benguela physical features and processes. Oceanogr Mar Biol Annu Rev 23:105-183

Shannon LV, O'Toole MJ (2003) Sustainability of the Benguela: ex Africa semper aliquid novi. In: Sherman K, Hempel G (eds) Large marine ecosystems of the world: trends in exploitation, protection and research. Elsevier, Amsterdam, p 227-253

Spear LB, Ainley DG (1997) Flight speed of seabirds in relation to wind speed and direction. Ibis 139:234-251

Summerhayes CP, Hofmeyr PK, Rioux H (1974) Seabirds off the southwestern coast of South Africa. Ostrich 45:88-109

Tremblay Y, Bertrand S, Henry RW, Kappes MA, Costa DP, Shaffer SA (2009) Analytical approaches to investigating seabird-environment interactions: a review. Mar Ecol Prog Ser 391:153-163

Tuck GN, Polacheck T, Croxall JP, Weimerskirch H, Prince PA, Wotherspoon S (1999) The potential of archival tags to provide long-term movement and behaviour data for seabirds: first results from wandering albatross Diomedea exulans of South Georgia and the Crozet Islands. Emu 99:60-68

Tuck GN, Polacheck T, Bulman CM (2003) Spatio-temporal trends of longline fishing effort in the Southern Ocean and implications for seabird bycatch. Biol Conserv 114: $1-27$

Tynan CT (1998) Ecological importance of the Southern Boundary of the Antarctic Circumpolar Current. Nature 392:708-710

Editorial responsibility: Rory Wilson, Swansea, UK
Watkins BP, Petersen SL, Ryan PG (2008) Interactions between seabirds and deep-water hake trawl gear: an assessment of impacts in South African waters. Anim Conserv 11:247-254

Weimerskirch $\mathrm{H}$ (2007) Are seabirds foraging for unpredictable resources? Deep-Sea Res II 54:211-223

Weimerskirch H, Jouventin P, Mougin JL, Stahl JC, Van Beveren M (1985) Banding recoveries and the dispersion of seabirds breeding in French austral and Antarctic territories. Emu 85:22-23

Weimerskirch H, Doncaster CP, Cuenot-Chaillet F (1994) Pelagic seabirds and the marine environment: foraging patterns of wandering albatrosses in relation to prey availability and distribution. Proc Biol Sci 255:91-97

Weimerskirch H, Catard A, Prince PA, Cherel Y, Croxall JP (1999) Foraging white-chinned petrels Procellaria aequinoctialis at risk: from the tropics to Antarctica. Biol Conserv 87:273-275

Weimerskirch H, Capdeville D, Duhamel G (2000a) Factors affecting the number and mortality of seabirds attending trawlers and long-liners in the Kerguelen area. Polar Biol 23:236-249

> Weimerskirch H, Guionnet T, Martin JSSA, Costa DP (2000b) Fast and fuel efficient? Optimal use of wind by flying albatrosses. Proc Biol Sci 267:1869-1874

Wilson RP, Ducamp JJ, Rees G, Culik BM, Niekamp K (1992) Estimation of location: global coverage using light intensity. In: Priede IMSS (ed) Wildlife telemetry: remote monitoring and tracking of animals. Ellis Horward, Chichester, p 131-134

Woehler EJ (1996) Concurrent decreases in five species of Southern Ocean seabirds in Prydz Bay. Polar Biol 16: 379-382

Woehler EJ, Raymond B, Watts DJ (2003) Decadal-scale seabird assemblages in Prydz Bay, East Antarctica. Mar Ecol Prog Ser 251:299-310

Woehler EJ, Raymond B, Boyle A, Stafford A (2010) Seabird assemblages observed during the BROKE-West survey of the Antarctic coastline $\left(30^{\circ} \mathrm{E}-80^{\circ} \mathrm{E}\right)$, January-March 2006. Deep-Sea Res II 57:982-991

Zuur AF, Ieno EN, Walker NJ, Saveliev AA, Smith GM (2009) Mixed effects models and extensions in ecology with R. Springer, New York, NY

Zwally HJ, Comiso JC, Parkinson CL, Cavalieri DJ, Gloersen P (2002) Variability of Antarctic sea ice 1979-1998. J Geophys Res 107:3041 doi:10.1029/2000JC000733

Submitted: May 28, 2010; Accepted: August 23, 2010

Proofs received from author(s): October 4, 2010 